2018-05

\title{
Community resilience in rural China: the case of Hu Village, Sichuan Province
}

\section{Wilson, Geoffrey}

http://hdl.handle.net/10026.1/11176

\author{
10.1016/j.jrurstud.2018.03.016 \\ Journal of Rural Studies \\ Elsevier
}

All content in PEARL is protected by copyright law. Author manuscripts are made available in accordance with publisher policies. Please cite only the published version using the details provided on the item record or document. In the absence of an open licence (e.g. Creative Commons), permissions for further reuse of content should be sought from the publisher or author. 
RURAL_2017_557.R1

Journal of Rural Studies

Vol. 60, 2018

\title{
Community resilience in rural China: the case of Hu Village, Sichuan Province
}

\begin{abstract}
Geoff Wilson
School of Geography, Earth and Environmental Sciences, University of Plymouth, UK Zhanping Hu

School of Geography, Earth and Environmental Sciences, University of Plymouth, UK Sanzidur Rahman

School of Geography, Earth and Environmental Sciences, University of Plymouth, UK
\end{abstract}

\section{$\underline{\text { Address for correspondence }}$}

Geoff Wilson

Professor of Human Geography

School of Geography, Earth and Environmental Sciences

University of Plymouth

Drake Circus

Plymouth, PL4 8AA

Phone: $+44-1752-585981$

Fax: $+44-1752-584710$

E-mail: gwilson@plymouth.ac.uk

March 2018 


\title{
Community resilience in rural China: the case of Hu Village, Sichuan Province
}

\begin{abstract}
Building on conceptual frameworks to assess community resilience developed by Emery and Flora (2006) and Kelly et al. (2015), this study analyses the resilience of Hu village (Sichuan, China). The resilience of the village is assessed in the face of multiple and complex slow- and fast onset anthropogenic disturbances, especially the impacts of globalisation and modernisation, which have substantially transformed Chinese society. Hu village is typical for a rural community in transition affected by industrialisation, deagrarianisation, counterurbanisation and changing stakeholder expectations and opportunities. This has been accompanied by agricultural depopulation, outmigration, increasing non-farm employment, declining agricultural incomes, and associated social and psychological changes - processes that have decreased community resilience. Overall, $\mathrm{Hu}$ village emerges as only moderately resilient with tendencies for a further weakening of resilience. While economic, social and cultural domains are (still) moderately resilient, the natural and political domains show weak resilience. Building on critical studies of Chinese rural areas (e.g. Ye and He, 2008; He, 2010; Huang et al., 2010) the study concludes by arguing that Chinese government policies need to be substantially realigned if the resilience of rural communities such as $\mathrm{Hu}$ village is to be improved.
\end{abstract}

\section{Introduction}

The notion of community resilience is gaining increasing importance in contemporary society, especially as many communities around the world appear to be gradually losing resilience in the face of challenges such as climate change, outmigration of young people and socioeconomic ruptures (Rigg, 2006, 2007; Wilson, 2012a; Kelly et al., 2015; Wilson et al., 2018). Resilience is generally understood as the ability of a system, community or society exposed to slow- or fast-onset shocks/disturbances to resist, absorb, accommodate and recover from shocks/disturbances including through the preservation and restoration of its essential basic structures and functions (Wilson, 2012a). Often it is not the magnitude of a single event which determines whether a 'disaster' is considered to have occurred but a combination of circumstances, including conflict, poverty and environmental degradation, the protracted 
legacies of past events, or a cascade of events caused by interdependencies in a system, which have affected the capacity of a community to respond (Brown, 2014; Wilson et al., 2018).

Hitherto the focus of resilience research has been largely on communities in developed countries, with more limited emphasis on developing or transition economies (Rigg et al., 2012). There is a particular gap in research in countries such as China that are currently undergoing rapid urban and rural change and where rural communities are facing unprecedented transformations (Wang, 2016; Tian, 2016). Like many other transition economies, in China research on themes associated with resilience has gradually increased in importance over the last few years (e.g. even studies investigating issues such as the resilience of the Chinese Communist Party, see Hillman, 2014, Meng, 2016). In China large-scale fastonset shocks such as the 2008 Sichuan earthquake have generated greater interest in understanding community resilience (e.g. Wang et al., 2009, 2010; Fu et al., 2014; Li et al., 2016). To better rebuild local communities devastated by the earthquake the government launched the 'Post-disaster Reconstruction Regulation for the Sichuan Earthquake' in 2008 which stressed that reconstruction of communities should take a comprehensive approach with an emphasis on economic and social reconstruction and environmental protection. Yet, Chinese studies about post-disaster reconstruction generally do not refer to the term 'community resilience', although there are studies that have investigated complex processes of the reconstruction and recovery at local level that include proxy resilience indicators such as economic growth, infrastructure rebuilding, social governance reforms, as well as cultural and environmental restoration (e.g. Li, 2017). Chen (2014), for example, found that affected communities were not only damaged by the earthquake but also by the subsequent statedominated top-down reconstruction process which further damaged endogenous social relations. Although Chen did not specifically refer to notions of 'resilience', his findings suggest that community resilience was considerably weakened by both the disaster and the 
state-led reconstruction process. Some studies have also pointed to the importance of the restoration of social memories associated with community reconstruction after the earthquake (e.g. Wen and He, 2016). Researchers have particularly highlighted the importance of rebuilding post-disaster social relations, and that reconstruction should not only focus on restoration but should also improve resilience to deal with potential future disasters (e.g. Li et al., 2009; Jiang, 2017). Li (2017) reviewed Chinese disaster studies for 2008-2017 and found that there was an upsurge in research after 2008, with key themes including resilience proxies such as post-disaster reconstruction, social, economic and cultural transitions and adaptions, coping approaches, or making better use of local knowledge.

Yet, this increasing interest in resilience-related themes to natural hazards has hitherto not generated studies investigating slow-onset and less traumatic disturbances affecting Chinese rural communities that are facing unprecedented socio-economic and cultural change. This highlights that there is still a paucity of the use of the term 'resilience' in Chinese policy discourse and that resilience is primarily conceived of in terms of resilience to natural disasters rather than having wider social and economic meaning. Key reasons for the paucity of resilience research on Chinese communities (both rural and urban) are both the continuing political opaqueness of the country making investigation of subtle and complex socio-political transitions difficult, and the still formidable language/cultural barriers for many Western researchers affecting in-depth qualitative work.

Using a case study of a rural village in Sichuan province (China), this study analyses the resilience of this community in the face of multiple and complex slow- and fast onset disturbances. Resilience will be assessed against a backdrop of natural and anthropogenic disturbances as conceptualised by Wilson (2012a). Although China faces regular natural catastrophes challenging the resilience of rural communities (Fu et al., 2014; Li et al., 2016), the key focus will be on anthropogenic disturbances, especially the impacts of globalisation 
and modernisation. As Rigg (2006) highlighted, rural communities in transition economies such as China have increasingly changed from production to consumption-oriented locations, driven by processes such as industrialisation, deagrarianisation, counter-urbanisation and changing stakeholder expectations and opportunities. This has often been accompanied by agricultural depopulation, outmigration, increasing non-farm employment, declining agricultural incomes, and associated social and psychological changes (Rigg, 2001) - processes that often decrease community resilience (Wilson, 2012b; Wilson et al., 2016). Building on Rigg (2007), the focus will specifically be on community-level processes and structures, networks and stakeholder interactions. Specific emphasis will be placed on investigating the characteristics of the case study community, the role that economic, social and cultural factors play in shaping community resilience (e.g. attitudes towards agriculture as an economic activity, community values and cohesion, structure of family relations, intra-household labour divisions, family labour division, pluriactivity), as well as discussing the importance of the changing policy framework at national and local levels and demographic changes (e.g. geriatrification, gender, family structures and types) for understanding community resilience.

\section{Understanding rural community resilience in China: concepts and issues}

Building on critical resilience studies (e.g. Miller et al., 2010; Wilson, 2010, 2012a, 2015), this study will use the notion of resilience as a normative concept based on the assumption that resilience can be situated along a spectrum of 'good' resilience and 'bad' vulnerability, where resilience-vulnerability are seen as oppositional terms situated on the same spectrum and where resilience is a desirable or better outcome. Only a normative resilience concept that sees resilience as a positive goal to be achieved will allow directional policy-making that aims at 
reducing vulnerability, whereby the ultimate yardstick for assessing resilience is the survival of a community as a cohesive unit able to withstand future shocks and disturbances. This study will, therefore, refer to notions of 'strong', 'moderate' and 'weak' resilience, whereby weak resilience is seen as synonymous with strong vulnerability.

To assess resilience at community level, this study will use the conceptual framework developed by Emery and Flora (2006) and Kelly et al. (2015) which suggests that social, cultural, natural, economic and political/institutional/governance-related factors need to be taken into account to understand how 'resilient' a community is (Figure 1). Although obtaining a full set of information on all these factors can be challenging, one key advantage of this framework is that it can be applied to any community. Many authors have emphasised the importance of understanding the complex interplay between various 'domains' for understanding community resilience (e.g. Emery and Flora, 2006; Buikstra et al., 2010; Wilson, 2012a), suggesting that community resilience will be strongest where the different domains intersect, provided these domains are well developed. As Figure 1 suggests, There are close interlinkages between the five domains and they broadly have equal 'weighting', and therefore weakening one domain (through outmigration for example) can also affect other domains (by reducing social capital, for example). Processes affecting community resilience are, thus, nonlinear, interlink in complex ways, and are often cumulative (Wilson, 2012a). Kelly et al.'s (2015) model also implies that communities can never be fully resilient as they always contain certain elements/processes that are contributing to vulnerability. Building on Resilience Alliance (2007), Wilson (2012a) and Kelly et al. (2015), certain assumptions will be made about which factors and processes raise or lower community resilience, some of which are relatively well established in the literature and relatively 'neutral', while others are more subjective and depend on the positionality of the researcher (Table 1). 


\section{Insert Figure 1 in or near here}

\section{Insert Table 1 in or near here}

Many studies highlight how economic factors influence community resilience (Buikstra et al., 2010; Brown, 2014), although much debate exists about the possible relationship between embeddedness of communities into capitalist and globalised economic networks or, in the case of transition economies such as China, about how the integration of rural areas into a more market-driven economy has affected community resilience (Table 1). In particular, the question whether globalisation may facilitate more resilient pathways by providing more wide-ranging opportunities for development is still hotly debated (Wilson, 2012b). Economic drivers that are often seen to exacerbate the vulnerability of communities include poverty (i.e. lack of resources to implement endogenous resilient pathways; Rigg, 2001), over-dependency on external forms of income (e.g. remittances or subsidies; Huang et al., 2010) or high income inequalities which can weaken community cohesion, trust and networks (Rigg, 2006; Kelly et al., 2015).

In China, the most dramatic economic changes in the past decades have occurred in urban areas linked to a state-led gradualist transition from a planned economy to a market economy which has led to a rapid rise of urban areas acting as magnets for the rural poor. This great 'liftoff' started in 1978 when the Communist Party began loosening rules that ensured that farmers stayed on the land to produce food. From the late 1970s farmers gradually gained more freedoms, especially to farm their own plots of land and sell their produce privately (decollectivisation). This led to a re-invigoration of China's traditional smallholder intensive farming system characterised by small-scale 'peasant' farms ( $<2 \mathrm{ha})$ with a few state controlled large agribusinesses. Since 2005, government policies have provided farmers with subsidies (e.g. for grain production, machinery, micro-credits) to increase agricultural production (Huang 
et al., 2010). Simultaneously, Chinese agriculture has been progressively integrated into international markets and, since China's accession to the WTO in 2001, agricultural prices in China have become more closely linked to those of international markets. From the 1990s onwards rural-urban migration became the most important pathway for farmers to find offfarm employment (Xia, 2016), with an estimated 200-300 million rural Chinese (mostly men) having permanently or temporarily migrated to urban areas - a transition that is far from complete in the late 2010 s and with ongoing repercussions for rural community resilience.

The social domain is similarly crucial for resilience because it mediates the relationship between economic, cultural and environmental components of a community (see Figure 1). Rural residents are social actors who exert agency according to specifically situated social relations and cultural norms. Key social factors include community member interactions such as relationships, trust, engagement of young and old people, conflict resolution processes, strength of networks, learning and communication pathways, bonding and bridging capitals, cooperation, as well as community 'cohesiveness' (Rigg et al., 2012). These factors affect community resilience, as well developed social processes are usually a sign of strong adaptive capacity to deal with shocks/disturbances. Communities with weak social capital allow practices that enhance vulnerability, collective concerns are more likely to be overridden by powerful stakeholders, and community interests may become fragmented (Wilson et al., 2016). Outmigration of young people is often a key cause of a weak social domain, and is a process closely linked to economic factors. Outmigration is a particularly important factor to consider in any community setting as it is both a driver for vulnerability (e.g. loss of social memory and skills) as well as a response to declining resilience (i.e. young people leave villages due to lack of opportunities; see Table 1).

Outmigration particularly leads to ageing/geriatrified communities which affects social dynamics, disrupts inter-generational communication, and interrupts social memory through 
loss of experience and knowledge. Once social memory is lost, it can no longer be used to address shocks/disturbances (Wilson, 2015). As Table 1 highlights, these social processes have been largely negative for resilience, although remittances can have positive effects (De Brauw and Rozelle, 2003). As a result of migration, local institutions may fail to adapt which can lead to lowering bonding capital through break-down of personal exchange, weakening of community cohesion, and the breakdown of communities of common ideologies and sets of rules. Chinese rural-urban migration is, nonetheless, tempered by the 'hukou' (household registration) system - an instrument of social stability in China's planned economy - which means personal status is classified by either agricultural/non-agricultural residential location and socio-economic eligibility to services. The hukou system, therefore, acts like an internal passport as rural migrants cannot become legal residents in cities and have to regularly commute between cities and their original villages ${ }^{1}$. Linked to this quest for modernity, agriculture in China has been widely downplayed not only by non-rural stakeholders but also by rural residents themselves. Through the rhetoric of urban/rural difference rural space and rural residents have been culturally construed as 'backward' and 'traditional' (Lei, 2003), inferior to urban residents who are associated with notions of 'modern', 'progressive' and 'promising' (see also Rigg et al., 2012, for similar patterns in other Asian countries). Ruralurban migration has, thus, particularly changed values associated with farming, with agriculture increasingly stigmatised by new social and cultural norms as a low status occupation, pushing young rural people out of agriculture (Xia, 2016).

The cultural domain, meanwhile, encompasses rites, ideologies, societal norms, traditions and conventions. Cultural factors are important as they include complex processes of human activities passed down not by genetic inheritance or environmental pressure but by teaching,

\footnotetext{
${ }^{1}$ In December 2015 the hukou system was modified following years of half-hearted tinkering. Migrant workers who have lived in a city for at least 6 months can now apply for special residency permits which provide some of the benefits of an urban hukou (e.g. access to health care; children $<15$ can attend local state school).
} 
imitation and conformism (Wilson, 2012a). Teaching and learning are, therefore, key to understanding the importance of cultural processes on community resilience, as is the moral component with community rules, traditions and rites that buttress 'way things are done' and which punishes infractions (see Table 1). Ultimately, cultural processes allow individuals to do things as part of a group that they would not be able to achieve by themselves. Ideologies are closely linked to how societal fashions and preferences change, and how such changes affect decision-making processes within communities (Rigg et al., 2012). These, in turn, affect the quality of social, economic, and natural domains at community level. Cultural factors can, therefore, be seen as the lattice of ideas that permeate communities and that constitute collective social consciousness.

Of key importance for community resilience are also the closely inter-linked factors of politics/policies, governance and institutional structures, i.e. forces from 'outside' linked to political and institutional developments that are difficult to influence by communities (Cumming et al., 2005). Key for resilience is the existence/absence of political will and the possibility to implement policies that help communities tackle shocks/disturbances, while entrenched local politics can lead to corruption, apathy, and a lack of integration of knowledge. The political domain is, therefore, often portrayed as 'conservative' or 'negative' for innovation, as it has a tendency to channel decisions into established pathways, rather than encouraging innovative thinking. These changes illustrate the dramatic impact of the Chinese state on everyday village life and agricultural productivity (Tian, 2016).

The final domain affecting community resilience is related to natural factors such as water quality and availability, the type and quality of soils, or the steepness and accessibility of the terrain (Kelly et al., 2015). Emphasis in this study will be placed on environmental repercussions of agricultural practices at community level and the general assessment of the health and well-being of the environment upon which residents of the case study community 
rely and how these interlink with economic, social, cultural and political/governance-related factors.

\section{Methods}

Our assessment of the resilience of a rural community in China is based on one case study community in SW China, whereby 'rural community' is understood as a group of socially interacting people living in a rural settlement and sharing one or more common ties. Rigg (2007) argued that studying a rural village community allows for an 'everyday geography' that connects ordinary people's everyday lives with macro-forces such as modernisation and globalisation. Focusing in-depth on just one community, thus, allows obtaining holistic and meaningful information about real-life events, life cycles of individuals and households, organisational and managerial processes at village level, information about neighbourhood change and, most importantly, about the complex socio-cultural interactions of community members associated with resilience processes highlighted in Table 1. For over 50 years, Chinese social scientists have analysed China's transformation through village case studies (e.g. He, 2010; Huang et al., 2010), suggesting that Chinese villages are still relatively independent economic, social and cultural entities. However, in the wake of modernisation, marketisation and globalisation, villages are no longer closed and autonomous entities and act increasingly as a bridge between state and society.

The village of Hu in the province of Sichuan (SW China) was selected as a case study. Sichuan province is the $4^{\text {th }}$ largest in China in population, $5^{\text {th }}$ largest in grain output, $6^{\text {th }}$ with regard to GDP in 2015 (36,800 yuan/capita GDP in 2015, below national GDP average), and with a relatively low rate of urbanisation (only $47 \%$ in 2015 ; national urbanization rate $57 \%$ ). Sichuan is in an early stage of industrialisation and urbanisation, and communities provide 
good opportunities as case studies to analyse their resilience while undergoing rapid transition. $\mathrm{Hu}$ village is a small rural community with 882 households (2938 residents), situated southwest of the Chengdu Plain ca 100km from Chengdu city and $10 \mathrm{~km}$ from the provincial town of Qingshen (Figure 2). The village economy is largely agricultural based with 142 ha of cultivated land of which the majority are paddy fields with a per capita farming area of only 0.05ha ('smallholder farming' typical for China). The per capita net income of each Hu village household was ca 5700 yuan in 2009 [ca US\$ 800].

\section{Insert Figure 2 in or near here}

$\mathrm{Hu}$ village was selected for three reasons. First, agricultural production is typical for southwest China, including rice, rape, corn, sweet potato, pig farming and sericulture (silk), while cash crops (e.g. rape, orange plantations) are increasingly common. Both subsistence cultivation and market production exist, which enables a comprehensive understanding of different agricultural trajectories. Second, different forces and processes are acting on economic processes in $\mathrm{Hu}$ Village which acting as 'meeting points' of various macro- and micro-level processes. Due to rapid urbanisation and industrialisation, many rural labourers have migrated to cities to seek money, while multiple job holding is a key livelihood strategy for many $\mathrm{Hu}$ villagers. As below analysis will show, this has greatly transformed the demography and socio-economic landscape of the community. Hu Village is, thus, a typical community with nearly $60 \%$ of households affected by migration. Third, Hu Village is tightly embedded in the national context of rural reforms initiated by central government, and village history reveals that every major state reform has affected the village.

A multi-method approach was used with quantitative and qualitative elements to triangulate findings that included a questionnaire survey, semi-structured interviews, focus groups, participant observation and analysis of secondary sources. Using a face-to-face questionnaire 
with 225 households (ca 1/4 of all households), quantitative data was obtained on demographic characteristics of respondents/household members, land use practices, land transfer processes, agricultural production, inputs and outputs, pluriactivity, socio-cultural practices and issues, non-farm activities and migration. Cluster sampling was used to avoid geographical or socioeconomic bias, to capture the diversity and heterogeneity, and to ensure coverage of the whole village.

Qualitative data was collected through semi-structured interviews (main researcher fluent in Mandarin) which targeted multiple stakeholders within and beyond the case study community. Interviews included information about viewpoints and attitudes about policies, farming, land use, migration and rural and socio-cultural change at community level (e.g. family relationships, education, community values). Farming respondents were selected through the questionnaire survey, while migrants were identified and selected through a snowballing strategy. Interviews with village cadres were straightforward as the female village head introduced the researcher to other cadres, although officials were reluctant to talk about anything but the 'official' party line. Overall 33 semi-structured interviews were held (15 farmers, 10 migrants, 3 village cadres, 2 businessmen, 2 township-level officials, 1 countylevel official). In addition, 8 focus groups (4-8 participants) provided invaluable information on resilience characteristics and processes, as well as more in-depth information about underlying reasons and logics behind residents' actions and thoughts (two male and female groups, one 'mixed gender group', two farmer groups, one for village cadres, one with residents without land, and one group with migrants).

Participant observation formed another important methodological pillar, with the researcher deliberately immersing himself for several months in the community's everyday rhythms and routines and developing relationships with village residents (Spradley, 2016). This included writing accounts of how these relationships developed in a daily field diary, what was 
learned from these observations, observing daily patterns and processes in the community, and at times just sitting back and watching activities unfold.

The final methodological step included analysis of secondary information such as official statistics about the community in the form of yearbooks (agricultural output, migration data, etc.), policy documents provided by the village committee, and various newspapers (province and county level).

Building on critical resilience studies and methodologies (Resilience Alliance, 2007; Kelly et al., 2015), quantitative and qualitative information was used to assess the resilience of the community based on key parameters/indicators highlighted in Figure 1 and Table 1 (above). While several indicators could be judged to be objective in nature (i.e. relative consensus about validity and 'direction' of indicator for assessing resilience; see Cumming et al., 2005; Resilience Alliance, 2007), some indicators were inevitably subjective and may only apply in specific socio-cultural contexts (see Table 1). Further, as most critical resilience studies highlight, most community resilience research is based on 'snapshots in time' with data collected in case study communities over relatively short time frames (Wilson et al., 2016) and this study is no exception. But resilience can only be assessed by investigating changes in community processes (Wilson, 2012a), and this study, therefore, ensured that contemporary resilience processes were conceptualised within a wider context of temporal change, i.e. only by understanding some of the key recent trends in Hu village was it possible to reach conclusions as to whether resilience has increased or decreased.

\section{The resilience of $\mathrm{Hu}$ village}


With regard to the economic domain, many macro-scalar economic transitions find specific reflection in $\mathrm{Hu}$ village. Several interviewees highlighted, for example, that like many Chinese communities the village has been transformed in recent years from an agricultural village dominated by smallholder farms and households to a community where the importance of farming has been marginalised - a typical example of gradual deagrarianisation (Rigg, 2007). As a result, non-agricultural income today makes up over $60 \%$ of village income and the most important source of income now comes from remittances (ca 50\% of non-farm income) sent by villagers who have migrated to urban areas. Overall, $60 \%$ of all households in $\mathrm{Hu}$ village have migrants who live permanently in urban areas, mainly in Chengdu (the provincial capital). Most $\mathrm{Hu}$ village migrants have secondary education and above, and a substantial fraction are no longer involved in farming. Indeed, Sichuan province is one of the key areas in China heavily affected by rural-urban migration (Fan, 2009), with 22 million rural labourers (ca. 1/4 of the population) having moved to urban areas (in and beyond Sichuan). As a result of migration remittances in $\mathrm{Hu}$ village, the average net household income today is about 11,000 yuan/year (ca £1200), higher than the Sichuan provincial average and higher than the national average of ca 9000 yuan/year. The fact that farming households are the poorest and nonfarming households have higher average incomes in $\mathrm{Hu}$ village explains why agriculture is increasingly marginalised. Indeed, China overall is now one of the least equal societies on the globe with a Gini coefficient of $0.46^{2}$ in 2015 , the highest in OECD countries. Thus, in many Chinese rural communities low agricultural income acts as a primary driver for residents seeking non-farm activities or to migrate (Xia, 2016).

For $\mathrm{Hu}$ village, the outcome of this inequality is reduction in farm labour and reduced farming outputs, although production of rice and rape (the two most important crops) is still broadly in line with regional and national averages (Hu and Rahman, 2015). Further, more than

\footnotetext{
${ }^{2}$ Gini coefficient $=$ standard measure of income inequality where 0 means total equality and 1 total inequality.
} 
one-fifth of $\mathrm{Hu}$ village households still continue to have $>80 \%$ of their income from farming, and overall agriculture still makes up ca $40 \%$ of all village income, with livestock farming the most important source of income (see Huang et al., 2010, for similar patterns in other parts of China). Most households, therefore, still produce some agricultural produce (e.g. chicken, horticulture), and crop farming is still practiced by households largely for subsistence. This highlights both that most households still have not yet completely lost the link to the land, and that agriculture continues to play an irreplaceable social security role for most village households. However, the sale of product locally does not generate much income, and a key constraint for increasing profits is the small parcel sizes of only ca $0.05 \mathrm{ha} /$ resident.

Migration has severely affected the type of agriculture practiced in $\mathrm{Hu}$ village, confirming results from other studies that have observed changes in cropping patterns and land use driven by migration (e.g. Rigg, 2001, for south-east Asia). Although Hu village is still characteristic of an 'integrated farming system' as a mixed crop/livestock smallholder system where family labour is important, diversification is now key for survival. While rice still occupies almost 2/3 of the farmed land (mainly for home consumption; surplus sold to market), rape is gaining importance, and citrus fruit and tree plantations (e.g. mulberry) are becoming more prominent. Nonetheless, cropping has declined over the past 20 years, especially as the increasing wealth of $\mathrm{Hu}$ villagers means that more food can be bought, and traditional small-scale livestock and poultry farming (pigs most important, followed by the rearing of chicken, duck and rabbit) is also in decline. In addition, the decline in traditional sericulture was particularly lamented by many respondents. Sericulture traditionally was the most important side-line for most $\mathrm{Hu}$ households, but has lost importance due to low payoff and high technological and labour requirements. As a result, most sericulturalists are elderly or household wives who cannot migrate. To deal with increasing lack of labour linked to outmigration (see also below), $\mathrm{Hu}$ residents have also begun planting trees (e.g. Osmanthus fragrans) which are less labour 
intensive, echoing Rigg's (2007) study that highlighted tree growing as a popular alternative to deal with lack of labour in Southeast Asia. Trees as cash crops are, therefore, primarily driven by rapid industrialisation and urbanisation in China.

Diversification in Hu village is particularly evident in two seemingly contradictory trends: subsistence-oriented crops still outweigh cash crops in terms of area cultivated, suggesting that the village can still be classified as a largely subsistence-oriented community, but simultaneously large livestock enterprises have emerged with $>100$ pigs (ca 20 households specialising in pig farming), three households have become specialised chicken producers, and two have established commercial duck enterprises with $>20,000$ animals (see also Rae et al., 2006). This suggests that the traditional smallholder crop and livestock mixed farming system will be progressively replaced by a more specialised, modernised, larger-scale and more market-oriented farming sector. Nonetheless, labour shortages are leading to more extensive use of land overall and crop diversity may be reduced (see also Rigg, 2007, for south-east Asia), but strategies vary depending on household labour and other economic conditions. Farming households with migrants, for example, have significantly reduced land-use intensity due to lack of labour.

These trends of both diversification and specialisation can be exemplified by two households. First, Respondent Z's household is typical of a highly diversified business that includes a small shop, 50 pigs (mainly tended by mother), a commercial fodder business (run by father), and the recent planting of ca $1000 \mathrm{~m}^{2}$ of former rice fields with Osmanthus trees. Second, the dangers of focusing on one key commodity where highlighted by Mr S, operator of the largest pig farm in Hu village (400 pigs), who argued that "pig production is a highly risky sector with very unstable pig prices, and rising grain prices keep raising feed costs and squeezing profit, so other family members work on other activities to reduce the risk and also sometimes subsidise pig production with cash when necessary". This suggests that with 
increasing levels of emigration from $\mathrm{Hu}$ village intensive pig farming is a likely to remain a risky strategy.

It is evident that the migration cycle greatly influences agricultural pathways in Hu village, and three typical patterns can be identified which affect nearly every farm household. First, family migrants may return home at certain times of the year to help on farms, but this happens in only ca $20 \%$ of $\mathrm{Hu}$ farming households suggesting that remaining farm families can no longer rely on help from their migrant children. While on average six different crops were planted by each household, fewer crops were planted in migrant households. Second, contract farming has also been used as a strategy to diversify farm pathways with two contract farming projects focused on sericulture and rape with links to companies that guarantee higher prices. Respondents suggested that this has deepened commercialisation of farming and has led to intensification on these farms, manifested by more material and labour inputs in contract farming. Third, due to the high cost of hired farm labour a key strategy of Hu villagers has been a shift towards modern capital-intensive labour-saving technologies which have gone hand-inhand with government incentives for mechanisation (see below).

These trends suggest several processes that are important for both strengthening and weakening community resilience. First, resilience has been weakened through both deagrarianisation and outmigration. In economic terms deagrarianisation has removed one of the stable economic elements of village life (albeit not very profitable in the past), while outmigration has increased the dependency of those remaining in the village on remittances (see also below). As there are few opportunities in Qingshen County for Hu villagers, only a small percentage of households has been able to opt for localised resilience strategies. In addition, as most non-farm jobs are found in urban areas (industry, service sector) the fortunes of many Hu village households have become tightly bound up with macro-economic conditions, increasing the economic dependency of Hu residents on the vicissitudes of global market forces. 
For instance, the 2008 global financial crisis and the decline of China's real estate industry since 2015 have caused millions of migrants to return to their rural hometowns in Sichuan, which has also been witnessed in Hu village.

Second, while outmigration and deagrarianisation inevitably have negative repercussions for resilience, they have nonetheless meant that diversification is emerging as a key economic survival strategy at household level. As Tong and Wen (2010) emphasised, rural economic diversification emphasises the integration between specialisation of labour at individual level and the professional diversification of livelihoods at household level. As the critical resilience literature suggests, diversification can often be associated with strengthening resilience as economic risk is spread over several development trajectories (multifunctionality) rather than just relying on one key source of income (monofunctionality) (Wilson, 2010).

Third, the fact that subsistence farming continues to be an important strategy despite rapidly modernising development pathways suggests that $\mathrm{Hu}$ villagers are aware that ensuring local supply of food continues to be crucial for community resilience at a time of rapid economic upheaval. However, increased engagement of $\mathrm{Hu}$ residents in non-farm activities has also been an important economic diversification strategy, with the result that the number of households engaged in farming is declining further every year. Nonetheless, agriculture is surviving in $\mathrm{Hu}$ village largely thanks to modern inputs and mechanisation (i.e. agricultural outputs are likely to remain relatively high), although labour loss linked to migration emerges an increasingly prominent problem, meaning that agriculture is playing a decreasing role in household livelihood strategies and is progressively marginalised. However, there remains still a strong attachment to the land, even among urban migrants, echoing Huang et al.'s (2010) findings for other parts of China. Overall, therefore, economic resilience strategies are complex in $\mathrm{Hu}$ village. Most households maintain a link to agriculture but with different intensity or 
specialisation, while migration households tend to reduce land use-intensity and agricultural diversity due to labour shortages.

Labour-saving farming technologies and mechanisation have also had substantial impacts on the natural domain in Hu village, most of which have been negative and have, therefore, lowered community resilience. Since the 1970s Hu village agriculture has no longer been organic and many artificial inputs (fertilisers, pesticides, herbicides) are today applied to a wide variety of crops (there are 3 fertiliser and pesticide shops in the village) (Hu and Rahman, 2016). Chemical fertilisers are often supplemented by small amounts of manure, but older farmers were more likely to use manure than young farmers because they were concerned about environmental impacts of artificial inputs. In addition, wealthier farmers in $\mathrm{Hu}$ village also tended to reduce the intensity of pesticide use for health reasons. However, households with migration (i.e. with less availability of farm labour), have tended to use more chemical fertilisers and less manure, highlighting that migration has an impact on soil management. Overall, yields have been sustained but crop diversity has been reduced, biodiversity has decreased due to increased use of chemical inputs, and traditional seed varieties have gradually been abandoned in favour of high-yielding varieties (Hu and Rahman, 2016). $\mathrm{Hu}$ village, therefore, witnesses substitution effects between modern chemical fertilisers and labourintensive manure among migration households, which has meant that crop productivity has been substantially improved and that production has, therefore, stayed more-or-less the same as in the past despite reduced farm labour. But time-saving agricultural technologies have also had an impact on water management for agriculture: a new technology used is the throwing of rice seedlings (rather than planting by hand) which saves labour (especially for migrant households) but, in return, needs ample water on rice paddies for several weeks. This has put more pressure on Sichuan water resources. In resilience terms, labour-saving farming technologies have, therefore, negatively impacted Hu village's natural resources. 
The social and cultural domains are equally complex in Hu village. Several socio-cultural trends identified in the literature on how globalisation and modernisation are affecting Chinese rural communities were also prevalent in $\mathrm{Hu}$ village. Many respondents, for example, expressed 'disappointment' with agriculture with statements such as "farming is annoying work” (Resp D), “agriculture is useless work now” (Resp Z), “farming is hopeless, [it means] working hard for little return" (Resp A), or "nobody wants to do farming except the elderly" (Resp F). In Hu village, therefore, agriculture, which used to be the mainstay of household livelihoods, has now become a sideline, increasingly perceived as a low status occupation. Focus group discussants suggested that being a government official or a businessmen are seen as jobs to aspire for and migrants who made their fortune elsewhere were particularly idolised (see also Croll and Huang, 1997). As a result, Hu's rural children are being told that "agriculture and the countryside have little future" (Resp Z) and moving out of agriculture is becoming the established cultural norm. Yet, at the time of survey there were only 45 nonagricultural hukou residents in Hu village (i.e. $<2 \%$ ) with some government officials, teachers, factory workers and some young adults having successfully shifted to an urban hukou (and thereby losing their entitlement to land).

The discussion of the economic domain already highlighted that outmigration has led to a shift from traditional technologies to modernised labour-saving technologies. This also has socio-cultural repercussions as the increased use of large machines such as combine harvesters marginalises women in farming leading to a more masculinised agriculture. Increased use of combine harvesters also means that migrants do not need to return home for harvest, with further repercussions for community cohesion. Yet, outmigration has not only led to a steady and dramatic decline in the agricultural population of the village (see above), but has also affected the gender balance. Although about half of the 2938 village residents are female, the age group 16-30 has more females than males due to the higher likelihood of young males 
migrating for employment. Due to migration of young people, the population pyramid is further skewed towards older residents (also linked to China's one-child policy) with people $>60$ making up a substantial part of the village population (21\% compared with a national average of $13 \%$ ). In addition, average $\mathrm{Hu}$ household size is now relatively low (3.0 people/household) and migration has led to many larger households being broken up into smaller units.

Outmigration has also severely affected the composition of the Hu nuclear family. While in the past most households had at least 3 generations living together, today $47 \%$ of households are nuclear family only (couple + children), although $44 \%$ of households still have a linear family pattern (consistent with the rest of China) and, overall, the family household still serves as major social unit. One-child families in particular have chosen to remain close to their extended family for support, but urban migration has contributed to the rising popularity of the linear family (77\% of linear families are migrant families). Nonetheless, married migrant couples often rely on linear family relationships which can provide invaluable help with custody of children, further exacerbated by the hukou problem which means that young migrant couples cannot permanently reside in urban areas and have to rely on rural family members to look after their children. Thus, left-behind elderly stay with left-behind children while migrant couples work outside the community. The migrant linear family greatly increases the labour burden for the left-behind elderly who have to do the farm work and look after the grandchildren, resulting in immense social pressures (Ye and He, 2008).

These changes in the social makeup of $\mathrm{Hu}$ village highlight several intertwined processes that all have repercussions for the resilience of the community. Geriatrification as a result of the sharp generational divide emphasises growing intergenerational divisions and relations. Other studies have highlighted the tendency towards an increasingly old farming population in China (Huang et al., 2010), as migration has led to left-behind women and left-behind elderly. Ye and $\mathrm{He}$ (2008) estimated that there are ca 20 million left-behind elderly in Chinese rural 
communities. In $\mathrm{Hu}$ village $70 \%$ of old residents $(60+)$ are the principal farmers in their households and in $40 \%$ of households agriculture is mainly undertaken by those aged $60+$, suggesting a pronounced inter-generational division within rural households as part of a collective and rational household strategy for maximising household security and labour efficiency. As elderly Respondent D highlighted,

\begin{abstract}
"For us, this arrangement [adult children work away, elderly stay behind] is the best option.
We are too old to migrate or do other non-farm jobs, and have to return to agriculture. Our adult children have to work in more lucrative sectors because the whole family is dependent on their income. We do farming to provide food for the whole family, and we take care of the grandchildren to allow our children to migrate".
\end{abstract}

$\mathrm{Hu}$ village youngsters, meanwhile, see their future in the cities:

\begin{abstract}
"There are no opportunities for us in the village, even in the county. Local salaries are low, infrastructure is poor, and people are traditional. I feel somehow left behind from my friends who are working in the city. After a while, I will leave again, there is no hope in the village."
\end{abstract}

This, however, places a high burden on old people left behind in villages, an issue described as an 'exploitative generational relationship' by Ye and $\mathrm{He}$ (2008). In Hu village, the elderly often have to pay for their grandchildren's education as their migrant children do not always send remittances back. In addition, old people struggle particularly with the new demands for land management (especially linked to mechanisation), although many elderly respondents argued that they see what they do as part of their family responsibilities and being part of what it means to be a 'good farmer'. Chen and Korinek (2010), therefore, suggested that geriatrification of farming forms an important aspect of a collective family strategy, with 
constant coordination and cooperation between generations within a household. Thus, geriatrification in $\mathrm{Hu}$ village has to be seen as an outcome of family division strategies and structural constraints, echoing Huang et al.'s (2010) findings from other Chinese rural communities.

In resilience terms, geriatrification has to be seen as a process lowering the resilience of $\mathrm{Hu}$ village, especially as it disrupts learning pathways and social memory between the generations and also tends to affect village cohesion (bonding capital). Indeed, interviews and focus groups revealed that $\mathrm{Hu}$ village youths increasingly put their own emotions above social expectations and see their role in society no longer about their responsibilities to the family and the local community but first and foremost about their own rights and needs. Collective identities and group membership have become secondary to personal preferences, with large repercussions for community resilience. Geriatrification particularly prevents young migrants from learning age-old skills related to sustainable smallholder farming, and, as several studies have highlighted, geriatrified rural communities often lack the vibrancy and energy needed at times of crisis (Wilson et al., 2016). That young and middle aged migrants are no longer part of key decision-making processes was a concern raised by several respondents. Most importantly, geriatrification is closely linked to over-empowerment of younger people (mainly because of increasing income gaps between young and old), the breakdown of the traditional parent-son relationship which was fundamental in traditional Chinese society $(\mathrm{He}, 2010)$, and the fact that traditions in rural families are considerably weakened during the encounter of young migrants with modernity. In Hu village respondents argued that this has led to increasingly rationalised family relations and an over-emphasis on material interests further exacerbating intergenerational divisions (see also Rigg et al., 2012). Respondents further argued that geriatrification has led to the breakdown of 'Confucian values', especially the key idea that a peaceful society is built on the family as an extended, stable unit of several generations under 
one roof, each with a distinct social role and status. Indeed, all respondents were affected by changes to family ties and dispersed kinsfolk across vast distances, and it was evident that notions of family and identity have struggled to keep up with $\mathrm{Hu}$ village's accelerated modernisation.

Feminisation of agricultural production is also a key concern for $\mathrm{Hu}$ village, linked to the fact that nearly $70 \%$ of migrants in $\mathrm{Hu}$ village are male. Chinese rural women are more likely to remain in agriculture than men (e.g. Fan, 2009), and this was also evident in $\mathrm{Hu}$ village where about $2 / 3$ of full-time farmers were female, while men tended to dominate in other occupations such as employment in local non-farming enterprises, self-employment, or working as government officials. These gender divisions are nothing new as the traditional intra-household gender division of 'male outside-female inside', deriving from Chinese Confucian traditions, still dominates rural families (Fan, 2009), although the extent and magnitude of male outmigration from rural communities is unprecedented. As a result, 'leftbehind-women' stay in villages to take care of children (Lei, 2003), and in Hu village ca 30\% of households have 'left-behind-women'. Some typical comments by left-behind-women included: "if there were no old people to support I would definitely join my husband" (Resp M), or "I have stayed for my son's education, otherwise I would also go away for work" (Resp L). Nonetheless, some left-behind-women have shown initiative in creating diverse and buoyant diversification activities (e.g. planting mushrooms, raising rabbits, bamboo weaving), although it was evident that many also yearned for urban modern lifestyles and increasingly abhor farming especially as considerable agricultural workloads are placed on older women.

This feminisation of economic pathways in $\mathrm{Hu}$ village has substantial implications for community resilience, especially as migrating males tend to be the ones more exposed to modernity and a rise in material interests, further exacerbating gender divisions within current rural families and acting as potential drivers of family division (Fan, 2009). Although $\mathrm{Hu}$ 
village families are using flexibility, livelihood security and family division to achieve household-level resilience, the feminisation of rural life in $\mathrm{Hu}$ village reduces community resilience.

Education is often seen as the key way out of agriculture (Lei, 2003), and De Brauw and Rozelle (2003) highlighted that one year of additional education in China raises non-farm wages by as much as $6 \%$ and results in $8 \%$ higher migration, highlighting that the migratory population has higher education. This was also the case in $\mathrm{Hu}$ village where parents invest a lot of money and time in better child education. Rural schools in Hu village are poor and, as a result, $\mathrm{Hu}$ village farmers often stop farming and take on other jobs to pay for their children's education elsewhere. Indeed, only $1.3 \%$ of sample households with children in education were full-time farmers and many were migrant households. In resilience terms education, therefore, emerges as a significant driver for rural non-farm job diversification and a 'good farmer' was seen by many respondents as one who can pay for children's education. However, the hukou system often prevents rural children from entering city schools and universities and, overall, the national education policy continues to be unfavourable to rural migrants.

The multifaceted changes engendered by these socio-cultural processes in $\mathrm{Hu}$ village have been profound. It is evident from respondent's answers that the quest for modernity is increasingly important, further exacerbating the urban/rural divide. Rural spaces in China are increasingly constructed as backward (Ngai, 2003; Riley, 2013), and the result has been that rural youth in $\mathrm{Hu}$ village yearn for modernised lifestyles in cities, further exacerbated by consumerism causing a 'one-way-mobility' (Chen and Korinek, 2010). This negative cultural construction of rural communities in the process of the Chinese quest for modernisation, therefore, lays down the ideological foundation for rural residents' attitudes and actions towards agriculture and rural communities which has also resulted in substantial physical changes to Hu village community: consumerism and external expression of wealth have led to 
a spate of non-traditional houses built in so-called 'urban' styles and the purchase of highstatus cars. The result has been that Chinese rural migrants no longer feel 'at home' when they are in their villages which, as Ngai (2003) emphasised, leads to weaker community cohesion and diminishing mutual help. Hu village thus epitomises the loss of the traditional Chinese village as an 'acquaintance community' (Fei, 1998) where villagers in the past were tightly interconnected within networks of family ties and community relations with strong community cohesion and strong reciprocity. With modernity, $\mathrm{Hu}$ village community has been gradually disassociated into a 'semi-acquaintance community' (He, 2010) or an 'atomised community' (Chen and Korinek, 2010) characterised by increasing individualism. Personal connections, interaction and trust have greatly diminished, further weakening community cohesion and lowering resilience. This was emphasised by the $\mathrm{Hu}$ village head who referred to the diminishment of mutual help in agriculture:

\footnotetext{
"Now villagers are more and more like strangers with each other. Many migrants don't return for so long that when we meet we don't know how to chat, just with a simple greeting. In addition, in the past, we helped each other a lot. For example, if a family wanted to build a house, then many villagers, relatives, and friends came to help for free. And then another who wanted to build a house, or do other things could also receive voluntary help from villagers. This mutual help was very common. But now it is rare. Everyone is thinking about money; no one is willing to help others for free. Everything is coupled with money."
}

This suggests a dramatic decline of community cohesion and reciprocity, and that $\mathrm{Hu}$ village community relations are built increasingly on market rules as the deep penetration of market economy ideologies has greatly disassociated villagers' personal relations. Today everything is seen as an economic transaction and 'free' mutual help among villagers is very rare - clear signs of diminishing resilience at community level. 
In the Chinese context the political domain will be particularly important (and complex) as the Chinese Communist Party continues to influence all levels of decision-making and regulates many community-based agricultural activities through subsidies and regulations. Although changes in policy trajectories since 1949 have affected Hu village just like any other Chinese rural community, the Chinese authorities have also implemented more region-specific policies. The 'Go-West-Campaign' of the 1990s and 2000s, for example, has been an important policy for the development of 12 provinces and autonomous regions from north-west to southwest China including Sichuan province. It has provided large-scale development opportunities for these provinces through substantial additional investment in infrastructure, environmental conservation measures and economic restructuring (away from agriculture). It has also supported agricultural production based on regional specialisations and has also been one of the key drivers for agricultural industrialisation in communities such as $\mathrm{Hu}$ village. Some of the larger-scale agricultural enterprises established recently in Hu village (mentioned above) have benefited from this scheme.

County policies affecting $\mathrm{Hu}$ village have focused on agricultural modernisation, including investments in infrastructure (especially irrigation and roadbuilding), and promotion of new agricultural technology, partly as a response to the loss of male migrants. This has not only provided incentives for $\mathrm{Hu}$ village for the establishment of new agricultural enterprises, but has also supported traditional agricultural practices such as sericulture. Almost all respondents agreed, however, that for $\mathrm{Hu}$ village subsidies have been one of the most important policies. Gradual increases in payments per ha have meant that subsidies have gained increasing importance for farming households in their decision whether to stay in agriculture or to migrate. $\mathrm{Hu}$ villagers who are receiving subsidies argued that they have been particularly important for the purchase of grain, artificial inputs, seeds and machinery. Hu village farmers receive ca 
1500/yuan/ha (of which grain subsidies make up ca 30\%) although sums are often smaller as many farmers have less than 1 ha.

Hu farmers generally expressed gratitude to the government for the receipt of subsidies but also argued that subsidies may reinforce trajectories that tend to weaken community resilience such as geriatrification and the feminisation of agriculture. However, a subsidised rabbit breeding programme was seen as very positive by respondents as it encouraged left-behind women to participate in more cash-generating activities. In addition, many respondents argued that as migrant families keep subsidies on land they lease out to other farmers, subsidies provide another incentive for migrants to keep their link to the land. However, there was also nearly unanimous agreement that no migrant farmer will return to farming because of subsidies, as subsidy payments levels are usually too low compared to migrant wages.

In Hu village government projects are, nonetheless, marred by an ossified bureaucracy and linear implementation systems that often cannot deal with increasingly complex local situations. Two government subsidised projects in $\mathrm{Hu}$ village illustrate the problem. First, the Autumn Potato Project (APP) established in 2009 provides free potato seed and artificial inputs (especially pesticides) while participants provide land, fertiliser and labour. However, respondents mentioned problems with project implementation, potato diseases and poor harvests as $\mathrm{Hu}$ village soils are not very suitable for potato growing. Official documentation nonetheless portrays the APP as a great success. Second, the Modern Pig Farming Project since 2010 provides subsidies for modern hoggeries and was well received in $\mathrm{Hu}$ village (ca 100 households participated with $70 \%$ building new hoggeries). Although respondents suggested that this was a 'good project' on the whole, after a few years only few have kept hoggeries, largely because farmers lacked experience and skills to manage large numbers of pigs. Yet again, official documentation has portrayed the pig scheme as a success, suggesting a substantial discrepancy between government rhetoric and farmer satisfaction. More positively 
rated have been government subsidies for forestry with the aim to increase forest cover to prevent land degradation (strengthening community resilience) and for the planting of Chinese medicinal herbs that also maintain and foster local traditional medicinal knowledge (again positive for resilience).

Overall, it is evident that government politics are all pervasive in Hu village and that the Chinese government continues to make substantial interventions in Chinese rural society. As a result, the political status of $\mathrm{Hu}$ village residents, i.e. whether they are members of the Communist Party or not, plays an important role with regard to opportunities open to villagers. Although questions on the role of the Communist Party could not be asked explicitly, implicitly many respondents agreed that membership of the Communist Party at times helped livelihood strategies and often party members would be the first to have access to, or receive, government aid. Hu village, therefore, highlights that Chinese communities are still constrained by political factors as to how much free expression of cultural processes are possible and have to also steer a pathway of compromise within the boundaries of accepted (Communist Party) ideological norms (Meng, 2016). It is here that assessments of resilience are at their most difficult and subjective (see Wilson 2012a, and Brown, 2014, for critical discussions) as the positionality of the researcher becomes key for the objective/subjective evaluation of impacts of a political system on community resilience. Our subjective assessment of the political resilience of $\mathrm{Hu}$ village is, therefore, that, as with other domains discussed in this study, political factors both strengthen and weaken resilience. Positive are policies and incentives that focus on keeping residents in the village (e.g. subsidies that help left-behind elderly and women) and schemes that focus on reducing land degradation (e.g. forestry projects), while negative are policies that have not managed to stem outmigration and the geriatrification of $\mathrm{Hu}$ village. In the near- to mid-term future it is, therefore, unlikely that government intervention will substantially alter the rapid modernisation and globalisation processes affecting communities such as $\mathrm{Hu}$ village. 


\section{Discussion and conclusions}

How resilient, then, is Hu village community? Above analysis has shown that in the economic domain there are propelling forces that both raise and lower resilience of $\mathrm{Hu}$ village. On the one hand, there is no doubt that - as in many other rural communities across China (Huang et al., 2010) - globalisation of China and associated modernisation have substantially increased wealth and incomes of $\mathrm{Hu}$ residents and have forced communities to increasingly diversify economically (multifunctionality $=$ increased resilience). However, simultaneously, inequalities between wealthy and poor(er) residents have increased: As De Brauw and Rozelle (2003) and Fan (2009) emphasised in their studies, households with migrants have generally seen their wealth increase (provided remittances are sent back) (increased resilience), while households that have opted for maintaining agricultural trajectories (non-migration) have generally seen their income levels increase less fast (increased vulnerability). The overall outcome suggests, therefore, moderate resilience of $\mathrm{Hu}$ village in economic resilience terms (Figure 3).

\section{Insert Figure 3 in or near here}

The critical resilience literature often argues that community resilience can be seen as a zerosum-game (Miller et al., 2010), and frameworks such as Kelly et al. (2015) - which this study has used as its conceptual springboard - may tend to reinforce the notion that raising resilience in one domain may inevitably lead to a lowering of resilience in another domain. Although this can be challenged empirically as there is clear evidence that some communities are more resilient than others and that some communities that have disappeared altogether evidently had 
no resilience (e.g. Kelly et al., 2015; Wilson et al., 2016), in the case of Hu village the notion of resilience as a zero-sum-game may be true with regard to one crucial domain: the strategy of many households (especially those with migrants) to buffer deagrarianisation trends linked to an increasing lack of farm labour by adopting labour-saving strategies such as mechanisation and especially the substitution of traditional environmentally-friendly farm practices (e.g. using animal manure as fertiliser) by artificial fertilisers, pesticides and herbicides (raising or at least maintaining resilience levels), which has led to the degradation of water and soil resources (weak resilience in the natural/environmental domain; see also $\mathrm{Hu}$ and Rahman, 2016). Agricultural substitution effects engendered by dramatic socio-economic upheaval in $\mathrm{Hu}$ village have, therefore, almost inevitable negative consequences for the resilience of the community (Figure 3).

The resilience picture with regard to the social and cultural domains is equally complex, and points towards weakening resilience trajectories. The social fabric of $\mathrm{Hu}$ village has been severely affected by globalisation and modernisation and the impacts on community networks, cohesion and ability for self-help have been, on the whole, negative. It comes as little surprise that what is possibly the largest ever seen rural-urban migration in human history has substantial effects on social and cultural processes in China's rural communities (Xia, 2016). The key factors identified here were linked to geriatrification (left-behind elderly) with inevitable negative repercussions for resilience, especially as greying communities are less vibrant and able to cope with sudden shocks and disturbances (Wilson et al., 2016) and are less able to pass on knowledge and skills to the younger generation (disruption of social memory), thereby weakening resilience (Wilson, 2015). Similarly the feminisation (left-behind women) of economic pathways (mainly but not exclusively linked to agriculture) is engendering problems of its own related to increasing gender divisions and the breakup of the traditional Chinese nuclear family which, until recently, formed the core of village social life. Inevitably, 
this has also had repercussions for the cultural domain in Hu village, especially through the marginalisation of agriculture as a key economic and cultural activity where rural areas are now construed as backward and traditional (weak resilience) and through the breaking down of long-established traditions and rites associated with village life because of increasing selfishness and profit-maximisation associated with the transition to a globalised capitalist society. Overall, therefore, social and cultural resilience of $\mathrm{Hu}$ village can, at best, be categorised as moderately resilient with tendencies for increasing vulnerability (see Figure 3).

As expected the political domain in Hu village was the most difficult to assess in resilience terms, although it is evident that the political concern for food security in China drives many current policies (e.g. agricultural subsidies) (Huang et al., 2010). Although there is clear evidence that government policy and institutions are attempting to buffer the impacts of globalisation and modernisation on communities such as $\mathrm{Hu}$ village (e.g. by attempting to address the issue of left-behind elderly and women), top-down policies are inevitably paradoxical in attempting to both encourage globalisation/modernisation while maintain smallholder farming in rural areas. As Tong and Wen (2010) and Tian (2016) have argued, government policies are, therefore, only able to scratch the surface with regard to buffering impacts of complex socio-cultural transitions. However, it could be argued that, although morally and ethically questionable by forcing rural migrants to keep a foothold in their rural communities, the hukou system has paradoxically raised the resilience of Chinese rural communities by ensuring that rural migrants have a reason to return to their villages (e.g. for seasonal help with farming; visiting their children who have limited access to urban education systems). As Huang et al. (2010) emphasised, the livelihoods of most Chinese rural migrants, therefore, still rely on a combination of migration and agriculture. Although highly reliant on the continuation of food production by left-behind elderly and women, this ensures at least to some extent continued agricultural production and, therefore, food security from local 
production (i.e. akin to strong resilience). Although value judgements particularly come to the fore when assessing the merits or disadvantages of the political domain (Kelly et al., 2015), above analysis suggests that the current socio-political situation in communities such as $\mathrm{Hu}$ village is nonetheless untenable in the long term, especially as village communities cannot be expected to rely increasingly on left-behind elderly and women to maintain current socioeconomic trajectories (weak resilience) (Figure 3). The resilience of $\mathrm{Hu}$ village with regard to the political domain has, therefore, to be interpreted as weak.

Overall, and echoing recent Chinese studies (Tian, 2016; Xia, 2016), Hu village depicts a pattern of mixed resilience processes (see Figure 3), with some vestiges of strong resilience (e.g. that many left-behind elderly and women have been willing to continue to maintain the economic, social and cultural life of the village; diversification activities with regard to farming and non-farming economic opportunities), many moderately resilient processes (e.g. maintenance of a relatively productive agriculture; young migrants still have a foothold in the village because of the hukou system; emergence of non-farming enterprises in the community), but also clear signs of vulnerability (e.g. geriatrification and feminisation of village economic activities; gradual breakdown of family and social networks; reduced community cohesion; increased environmental degradation). It is the latter processes that are of particular concern, as short- and mid-term trajectories are likely to further worsen the situation in communities like $\mathrm{Hu}$ village. Overall, therefore, Hu village can be described as (still) moderately resilient to future shocks and disturbances but it is also on a pathway of increasing economic, social, cultural, political and environmental vulnerability with trajectories that are likely to deteriorate in the near future (Figure 3). As Wang (2016) and Tian (2016) highlighted, this is sending out clear signals to Chinese policy-makers as to where some of the most urgent policy interventions may be needed if the authorities want to prevent further depopulation and economic marginalisation of the Chinese countryside. If we accept that resilience can be used as a 
normative concept that can inform policies (see introduction), more robust policies are needed to help left-behind elderly and women in rural communities and to strengthen community networks and cohesion by rediscovering strongly resilient community pathways.

$\mathrm{Hu}$ village and other Chinese rural communities are by no means alone in facing substantial problems related to outmigration of young people, geriatrification and the associated maintenance of the most basic social and cultural processes that villages have relied on for centuries (Wilson, 2012a). Indeed, many transition economies are dominated by agricultural modernisation regimes, have embarked on market-led neo-liberal economic reforms, are characterised by insecure property rights, and show tensions between the agribusiness and smallholder family farm model (Rigg, 2007). Resilience processes identified for $\mathrm{Hu}$ village also resonate with key issues highlighted in research using the 'sustainable livelihoods framework' which emphasises the urgent need for further internationalisation of research on community resilience (Lindenberg, 2002; Rigg and Oven, 2015). In many instances aspects of community resilience are already examined in development studies and investigations undertaken by aid agencies (e.g. Rasul et al., 2015; Jones and Tanner, 2015; IFRC, 2016), but often this research is couched in the language of resilience proxies associated with 'sustainable livelihoods' and, therefore, not easily accessible to the resilience research community. This nonetheless offers fruitful avenues for future research on the resilience of rural communities in China that may be able to use indicators of the livelihoods framework to investigate in greater depth key issues affecting the resilience of Chinese rural communities. At this stage, however, it is difficult to tell how representative findings from $\mathrm{Hu}$ village are with regard to both the resilience of rural communities in wider China or in other transition economies due to the absence of studies using similar approaches. It is hoped, therefore, that this study will be used both as a conceptual and empirical platform for further comparative resilience work and that it will also spark further interest among Chinese researchers in particular to critically engage with 
the resilience approach to study challenges faced by rapidly changing Chinese rural communities.

\section{Acknowledgements}

The authors wish to thank the community of Hu village, and especially the respondents who participated in the survey, for their cooperation and help. The authors acknowledge funding by the University of Plymouth, UK, for Zhanping Hu's $\mathrm{PhD}$ thesis which formed the basis for this article. Finally, the authors also wish to thank the anonymous referee for constructive comments on an earlier version of this article.

\section{References}

Brown, L. 2014: Global environmental change I: a social turn for resilience? Progress in Human Geography 38 (1): 107-117.

Buikstra, E. et al. 2010: The components of resilience: perceptions of an Australian rural community. Journal of Community Psychology 38 (8): 975-991.

Chen, F. and K. Korinek 2010: Family life course transitions and rural household economy during China's market reform. Demography 47 (4): 963-987.

Chen, S. 2014: The opportunities of ruins: a poster-disaster study of the 2008 Sichuan Earthquake (Feixu shangde Qiji: Wenchaun Dizhen Zaihou Chongjian Yanjiu). Unpublished PhD Thesis, China Agricultural University.

Croll, E.J. and P. Huang 1997: Migration for and against agriculture in eight Chinese villages. The China Quarterly 149: 128-146.

Cumming, G.S., Barnes, G., Perz, S., Schmink, M., Sieving, K.E., Southworth J., Binford, M., Holt, R.D., Stickler, C. and T. Van Holt 2005: An exploratory framework for the empirical measurement of resilience. Ecosystems 8: 975-987.

De Brauw, A.L. and S. Rozelle 2003: Migration and household investment in rural China. China Economic Review 19 (2): 320-335.

Emery, M. and C. Flora 2006: Spiralling up: mapping community transformation with community capital framework. Community Development 37: 19-30.

Fan, C.C. 2009: Flexible work, flexible household: labour migration and rural families in China. Research in the Sociology of Work 19: 377-408.

$\mathrm{Fu}, \mathrm{C}$., Leoutsakos, J.M. and C. Underwood 2014: An examination of resilience crossculturally in child and adolescent survivors of the 2008 China earthquake using the Connor-Davidson resilience scale. Journal of Affective Disorders 155: 149-153.

He, X. 2010: Keywords of rural society: a sketch of China's rural society in the early $21^{\text {st }}$ century. Shandong: Shandong People Press.

Hillman, B. 2014: Patronage and power: local state networks and party-state resilience in rural China. Stanford (CA): Stanford University Press.

$\mathrm{Hu}, \mathrm{Z}$. and S. Rahman 2015: Economic drivers of contemporary smallholder agriculture in a transitional economy: a case study of $\mathrm{Hu}$ village from southwest China. Singapore Journal of Tropical Geography 36: 324-341. 
Hu, Z. and S. Rahman 2016: Beyond a bottle of liquid: pesticide dependence in transitional rural China. Local Environment. 21(8):919-938.

Huang, J.K., Yang, J. and S. Rozelle 2010: China's agriculture: drivers of change and implications for China and the rest of the world. Agricultural Economics 41: 47-55.

IFRC [International Federation of the Red Cross and Red Crescent Societies] 2016: World disasters report 2016: resilience - saving lives today, investing for tomorrow. Geneva: IFRC.

Jiang, B. 2017: Post-disaster reconstruction and the rebuilding of disaster conceptions among Qiang ethnic people. Journal of Southwest Minzu University 7: 1-7.

Jones, L. and T. Tanner 2015: Measuring 'subjective resilience': using people's perceptions to quantify household resilience. London: Overseas Development Institute.

Kelly, C., Ferrara, A., Wilson, G.A., Ripullone, F. and A. Nole 2015: Community resilience and land degradation in forest and shrubland socio-ecological systems: evidence from Gorgoglione, Basilicata, Italy. Land Use Policy 46: 11-20.

Lei, G. 2003: Rural taste, urban fashions: the cultural politics of rural/urban difference in contemporary China. East Asia Cultures Critique 11 (3): 613-646.

Li, H., Qu, X. and M. Yan 2009: Social re-adaption, participatory reconstruction and antivulnerability development: reflections on the reconstruction of communities affected by the 2008 Sichuan earthquake. Social Science Research 3: 1-7.

Li, K. 2017: Ten-year studies of 'risk, crisis and disaster prevention'. Journal of Southwest Minzu University 8: 28-36.

Li, X., Wang, L. and S. Liu 2016: Geographical analysis of community resilience to seismic hazard in southwest China. International Journal of Disaster Risk Science 7: 257-276.

Lindenberg, M. 2002: Measuring household livelihood security at the family and community level in the developing world. World Development 30 (2): 301-318.

Meng, I. 2016: The development of grand mediation and its implications for China's regime resilience. The China Review 16 (1): 95-119.

Miller, F. et al. 2010: Resilience and vulnerability: complementary or conflicting concepts? Ecology and Society 15 (3): 11.

Ngai, P. 2003: Subsumption or consumption? The phantom of consumer revolution in 'globalizing' China. Cultural Anthropology 18 (4): 469-492.

Rae, A.N., Ma, H., Huang, J.K. and S. Rozelle 2006: Livestock in China: commodity-specific total factor productivity decomposition using new panel data. American Journal of Agricultural Economics 88(3): 680-695.

Rasul, G., Sharma, B., Mishra, B., Neupane, N., Dorji, T., Khadka, M. and S. Joshi 2015: Strategic framework for resilient livelihoods in earthquake-affected areas of Nepal.

ICIMOD Working Paper 2015/6. Kathmandu: ICIMOD [International Centre for Integrated Mountain Development].

Resilience Alliance 2007: Assessing resilience in social-ecological systems: a workbook for scientists. www.resalliance.org/3871.php (last accessed 20 December 2016).

Spradley, J.P. 2016: Participant observation. Long Grove (Ill.): Waveland Press.

Rigg. J. 2001: More than the soil: rural change in southeast Asia. New York: Prentice Hall.

Rigg, J. 2006: Land, farming, livelihoods, and poverty: rethinking the links in the rural South. World Development 34 (1): 180-202.

Rigg, J. 2007: An everyday geography of the global south. London: Routledge.

Rigg, J., Salamanca, A. and M. Parnwell 2012: Joining the dots of agrarian change in Asia: a 25 Year view from Thailand. World Development 40 (7): 1469-1481.

Riley, N.E. 2013: Gender, work, and family in a Chinese economic zone. Amsterdam: Springer. 
Tian, G. 2016: The rapid decline of villages and rural landscapes in China. Unpublished paper presented at the IGU International Conference on Land Use and Rural Sustainability, Xi' an (China), 17-20 August 2016.

Tong, Z.H. and T.J. Wen 2010: The transference of capital and departmental capital to rural areas and the organization of farming household economy: to query the path of specialised cooperatives. The Chinese Cooperative Economy Review 2: 8-28.

Wang, L., Shi, Z, Zhang, Y. and Z. Zhang 2010: Psychometric properties of the 10-item Connor-Davidson resilience scale in Chinese earthquake victims. Psychiatry and Clinical Neurosciences 64 (5): 499-504.

Wang, L., Zhang, Y., Wang, W., Shi, Z., Shen, J. and M. Li 2009: Symptoms of posttraumatic stress disorder among adult survivors three months after the Sichuan earthquake in China. Journal of Traumatic Stress 22 (5): 444-450.

Wang, J. 2016: Rural depopulation and its effects on settlements in the North China Plain. Unpublished paper presented at the IGU International Conference on Land Use and Rural Sustainability, Xi'an (China), 17-20 August 2016.

Wen, J. and W. He 2016: Reconstructing social memory in disaster areas: the example of the Shanghai social work empowerment service and the Ludian earthquake. Sociological Research 2: 170-193.

Wilson, G.A. 2010: Multifunctional 'quality' and rural community resilience. Transactions of the Institute of British Geographers 35: 364-381.

Wilson, G.A. 2012a: Community resilience and environmental transitions. London: Earthscan/Routledge.

Wilson, G.A. 2012b: Community resilience, globalization, and transitional pathways of decision-making. Geoforum 43: 1218-1231.

Wilson, G.A. 2015: Community resilience and social memory. Environmental Values 24 (2): 227-257.

Wilson, G.A., Quaranta, G., Kelly, C. and R. Salvia 2016: Community resilience, land degradation and endogenous lock-in effects: evidence from the Alento region, Campania, Italy. Journal of Environmental Planning and Management 59 (3): 518-537.

Wilson, G.A., Schermer, M. and R. Stotten 2018: The resilience and vulnerability of remote mountain communities: the case of Vent, Austrian Alps. Land Use Policy 71: 372-383.

Xia, W. 2016: Agricultural land and rural-urban migration in China. Unpublished paper presented at the IGU International Conference on Land Use and Rural Sustainability, Xi'an (China), 17-20 August 2016.

Ye, J.Z. and C.Z. He 2008: Lonely sunsets: the elderly left-behind in rural China. Beijing: Social Sciences Academic Press. 


\begin{tabular}{|c|c|c|c|}
\hline Resilience domain & $\begin{array}{l}\text { Community } \\
\text { resilience indicator }\end{array}$ & $\begin{array}{l}\text { Processes enhancing } \\
\text { community resilience }\end{array}$ & $\begin{array}{l}\text { Processes enhancing } \\
\text { community vulnerability }\end{array}$ \\
\hline \multirow[t]{7}{*}{ Economic domain } & $\begin{array}{l}\text { Community embeddedness } \\
\text { into capitalist and globalised } \\
\text { economy }\end{array}$ & $\begin{array}{l}\text { Increases community-level economic } \\
\text { opportunities }\end{array}$ & $\begin{array}{l}\text { Increases community dependency on } \\
\text { non-local income sources and } \\
\text { vicissitudes of global markets }\end{array}$ \\
\hline & Community wealth & $\begin{array}{l}\text { Enhanced personal and household } \\
\text { livelihood opportunities }\end{array}$ & Income inequalities at community level \\
\hline & \multirow[t]{2}{*}{ State subsidies/remittances } & $\begin{array}{l}\text { Well-targeted subsidies can enhance } \\
\text { community income }\end{array}$ & Increased dependency on remittances \\
\hline & & Increased household income & \\
\hline & Access to international trade & $\begin{array}{l}\text { Enhances marketing opportunities for } \\
\text { community-produced goods }\end{array}$ & Increases exposure to global markets \\
\hline & \multirow[t]{2}{*}{ Outmigration/urbanisation } & $\begin{array}{l}\text { Non-farm employment (diversification of } \\
\text { income sources) }\end{array}$ & \\
\hline & & Remittances boosting income & \\
\hline \multirow[t]{4}{*}{ Social domain } & \multirow[t]{4}{*}{ Outmigration/urbanisation } & Increased personal mobility & $\begin{array}{l}\text { Decrease in bonding capital; breakdown } \\
\text { of community cohesion and networks }\end{array}$ \\
\hline & & Improved personal livelihoods & Loss of social memory \\
\hline & & Increased empowerment of young women & $\begin{array}{l}\text { Ageing communities (geriatrification) } \\
\text { and left-behind children (reduced family } \\
\text { cohesion) }\end{array}$ \\
\hline & & & Breakdown of traditional rural family \\
\hline \multirow[t]{4}{*}{ Cultural domain } & \multirow[t]{4}{*}{ Outmigration/urbanisation } & Livelihood diversification & $\begin{array}{l}\text { Tendency for individualisation (loss of } \\
\text { community cohesion) }\end{array}$ \\
\hline & & $\begin{array}{l}\text { Opens rural society to modern (+ more } \\
\text { liberal?) ideas }\end{array}$ & Decline of parental authority \\
\hline & & & $\begin{array}{l}\text { Split households (reduced household- } \\
\text { level resilience) }\end{array}$ \\
\hline & & & Cultural marginalisation of agriculture \\
\hline \multirow[t]{4}{*}{ Political domain } & \multirow[t]{2}{*}{$\begin{array}{l}\text { State-led transition to market } \\
\text { economy }\end{array}$} & Increased economic opportunities & $\begin{array}{l}\text { Increased community dependency on } \\
\text { non-local income sources }\end{array}$ \\
\hline & & $\begin{array}{l}\text { Empowers rural communities to take } \\
\text { more control }\end{array}$ & Local institutions slow to adapt \\
\hline & \multirow[t]{2}{*}{$\begin{array}{l}\text { Government policies and } \\
\text { subsidies }\end{array}$} & Enhanced productivity (e.g. agriculture) & $\begin{array}{l}\text { Increased dependency on external } \\
\text { income sources and help }\end{array}$ \\
\hline & & & $\begin{array}{l}\text { Continued uncertainty re land rights and } \\
\text { 'hukou' }\end{array}$ \\
\hline \multirow[t]{2}{*}{ Natural domain } & \multirow[t]{2}{*}{$\begin{array}{l}\text { Deagrarianisation/agricultural } \\
\text { substitution effects }\end{array}$} & $\begin{array}{l}\text { Labour-saving strategies through } \\
\text { mechanisation }\end{array}$ & $\begin{array}{l}\text { Substitution of traditional } \\
\text { environmentally-friendly practices (e.g. } \\
\text { less use of manure) }\end{array}$ \\
\hline & & $\begin{array}{l}\text { Increased use of fertilisers, herbicides, } \\
\text { pesticides }\end{array}$ & Degradation of water and soil resources \\
\hline
\end{tabular}

Table 1: Key factors for the resilience and vulnerability of Chinese rural communities in relation to economic, social, cultural and political factors (Source: authors; after Croll and Huang, 1997; Yao, 2007; Huang et al., 2010; Wang, 2016; Tian, 2016; Xia, 2016) 


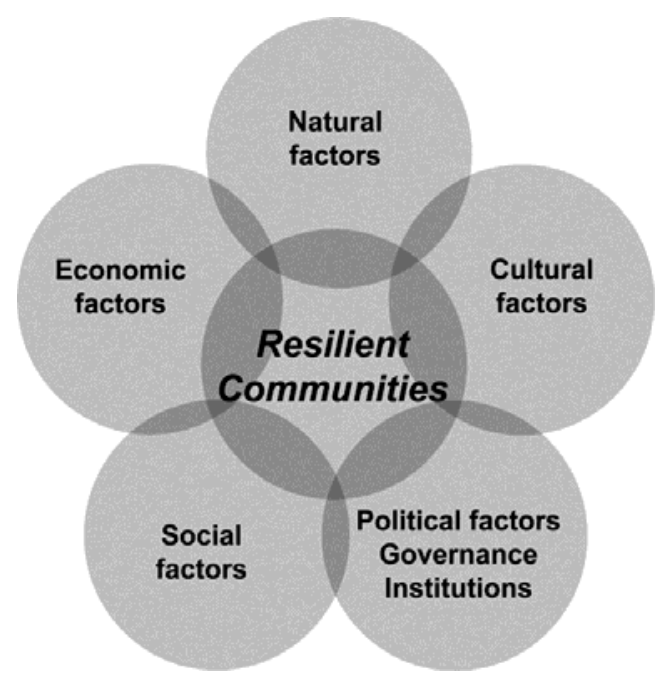

Figure 1: Conceptual framework for analysing resilient communities (Source: Kelly et al., 2015, 12) 


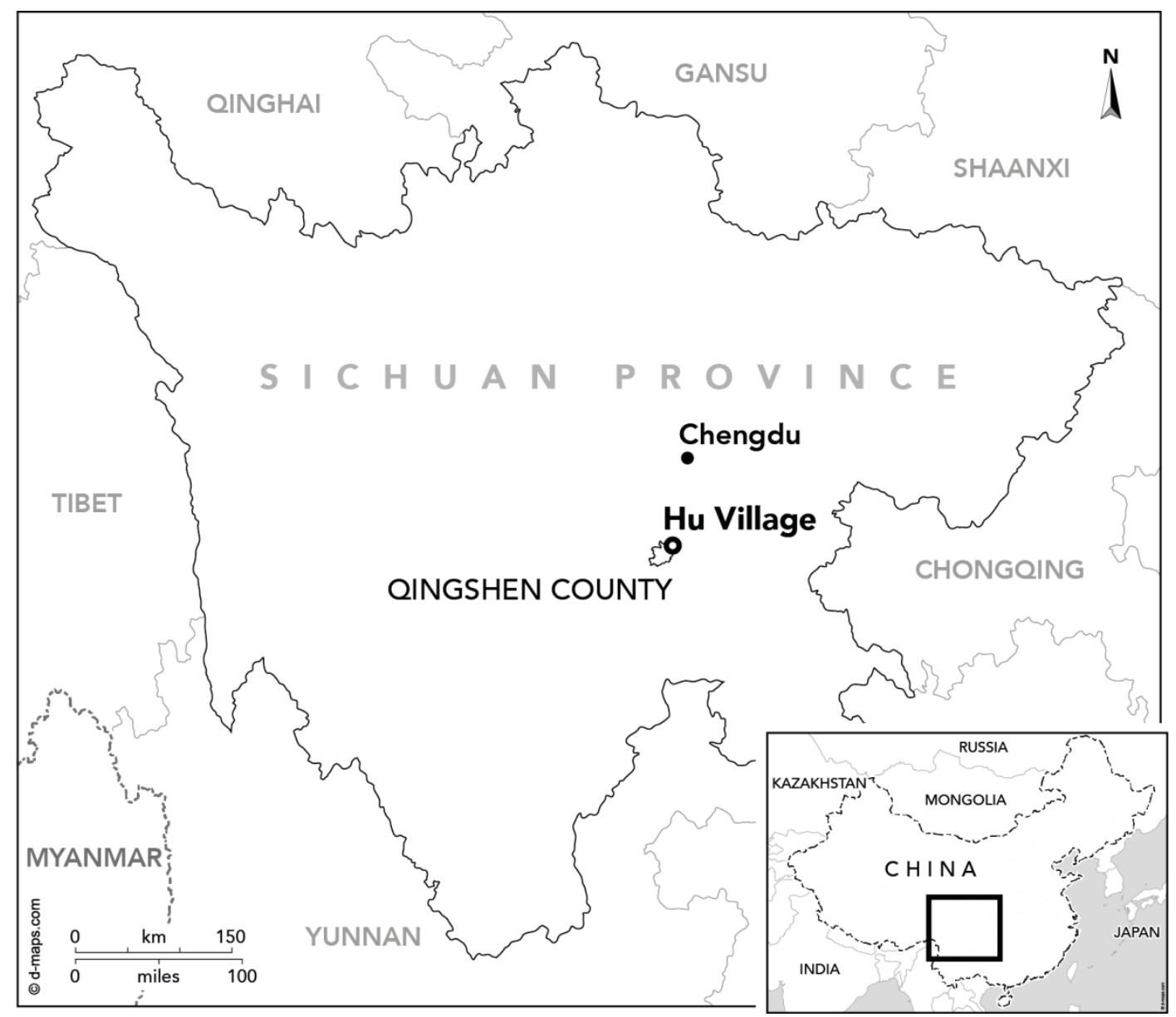

Figure 2: Location of Hu village in Sichuan Province (Source: authors) 


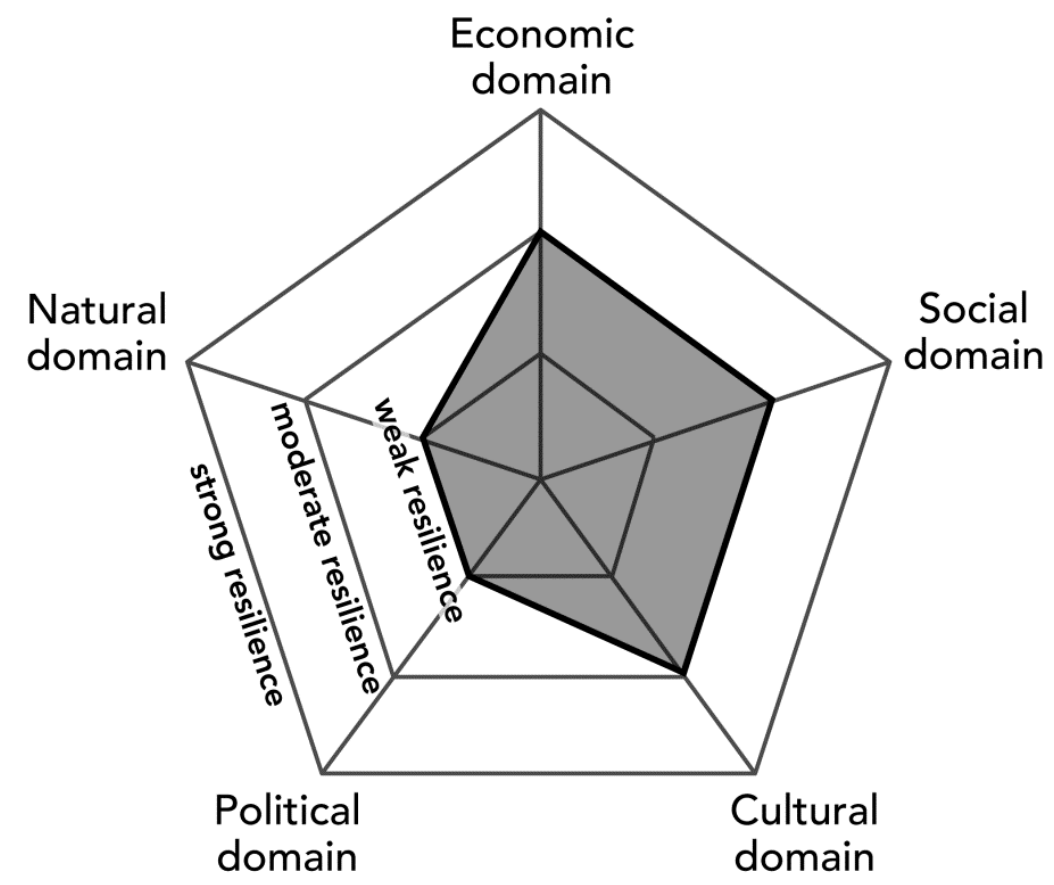

Figure 3: The resilience of $\mathrm{Hu}$ village based on economic, social, cultural, political and natural domains (Source: authors) 